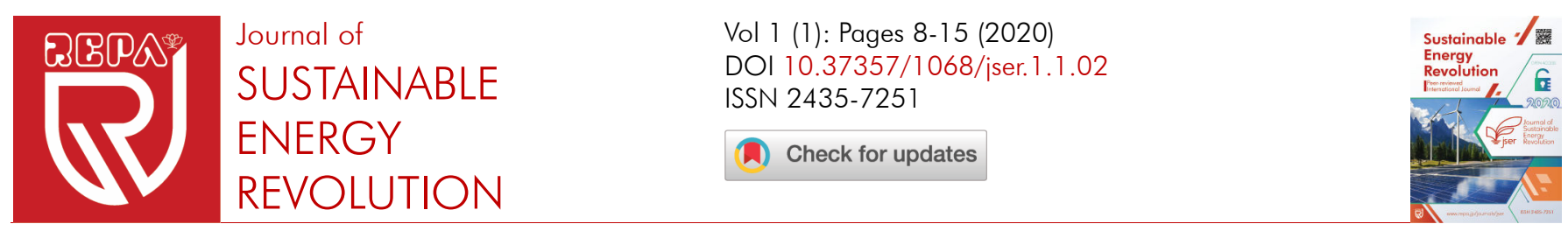

\title{
Renewable energy potential for sustainable development in Afghanistan
}

Ahmad Khalid Slimankhil ${ }^{1}$, Mohammad Abed Anwarzai ${ }^{1}$ Najib Rahman Sabory ${ }^{1}$, Mir Sayed Shah Danish ${ }^{1,2}$, Mikaeel Ahmadi $^{3}$ and Mohammad Hamid Ahadi ${ }^{4}$

${ }^{1}$ Department of Energy Engineering, Faculty of Engineering, Kabul University, Kabul, Afghanistan

${ }^{2}$ Strategic Reserch Projects Center, University of the Ryukyus, Okinawa, Japan

${ }^{3}$ Department of Electrical and Electronics Engineering, Faculty of Engineering, University of the Ryukyus, Okinawa, Japan

${ }^{4}$ Department of Academic Affairs, Research and Education Promotion Association (REPA), Okinawa, Japan

\section{Special Issue Article}

Open Access

Published

Keywords

- Afghanistan energy potential

- Afghanistan energy resources

- Sustainable development

- Socio-economic development

- Sustainable development goals (SDGs)

- Energy access

\section{ABSTRACT}

Afghanistan is one of the developing countries in South Asia with an enormous renewable and nonrenewable energy resources. Since 1893, utilization of secondary (modern) form of energy in Afghanistan has been pursued. The trends of sustainable energy provision have been reinforced after the post-conflicts in Afghanistan. The Sustainable Development Goal-7 (affordable and clean energy access) encourages nations to assess their resource development of renewable, affordable, and accessible energy. Unlike many developing countries that struggle to identify domestic sources of clean, sustainable energy, Afghanistan has hydro, solar, wind, and geothermal resources as assets. This literature review analyzes Afghanistan's potential for renewable energy to identify obstacles and challenges like security, economics, and technology. Using surveys conducted by national and international organizations. This research evaluates Afghanistan's progress in meeting SDG-7, identifies the main barriers for renewable energy development, and offers recommended solutions. This study reveals the facts of energy sector development in Afghanistan to enable students, researchers, and practitioners with an overview of the current situation and future direction of the energy sector. Also, this study offers a concise outlook for energy sector investors and donors at the national and international stages.

Received: January 16, 2020; Revised: March 14, 2020; Accepted: March 20, 2020; Published: June 05, 2020

\section{Introduction}

A nation's sustainable socioeconomic development relies on managing secure sources of domestic energy. While renewable energy is available, most of the world's energy comes from non-renewable resources. Which directly contributes to climate change and causes environmental problems that detrimentally affect quality of life. Non-renewable energy sources are responsible for $50 \%$ of global air pollution and $60 \%$ of emitted global greenhouse gases [1]. Consequently, reducing reliance on non-renewable sources decreases global carbon dioxide and greenhouse emission concentration, and mitigates long-term climate change effects. Renewable energy sources, in contrast, can meet the increasing global energy demand and sustaining global development goals while maintaining the environment. Whereas, global energy demand increased by $2.1 \%$ in 2017 , it is also expected to increase by $30 \%$ by 2035 [2]. In addition, 21\% of the world's population lacks access to electricity and use biomass as their primary source of energy [3].

Afghanistan with a geopolitical privilege has the merit of energy hub between South and Central Asia. Afghanistan is a landlocked country borders with the Islamic Republic of Iran, Pakistan, China, Tajikistan, Uzbekistan, and Turkmenistan [4]. As of April 2020, the population of Afghanistan is reported about 39 million $(38,722,255.0$ with an average medium age of 18.4 years), ranked number 37 in the list of the world countries by population with a density of 60 per $\mathrm{Km} 2$ (25.4\% urban residence) [5]. Afghanistan located between latitudes $29^{\circ} \mathrm{N}$ and $39^{\circ} \mathrm{N}$ and longitudes $60^{\circ} \mathrm{E}$ and $75^{\circ} \mathrm{E}$ that bestows plenty of solar and wind energy production potentials [6].

Reports indicate that only $30 \%$ of citizens of Afghanistan have access to electricity, and $80 \%$ of national electricity demands imports from neighboring countries [7]. While the rate of reliable electricity access is only between $10-15 \%$, Afghanistan is listed among the lowest access countries in the world [8]. In 2013, consumption per capita was $178 \mathrm{kWh}$, and expected to increase national electricity demands from 3,531 GW (2011) to $18,409 \mathrm{GW}$ (2032) [9]. Natural resources remain the primary source for approximately $85 \%$ of the population. Afghanistan like other developing countries, in addition to a low rate of modern energy accessibility challenge, has tried to overcome heavy reliance on import, deforestation and health issues due to excessive use of firewood and fossil fuel and etc. as a primary energy source and pollutant of air and environment [10]. Research has suggested that accessing and deployment of Afghanistan's renewable energy resources can meet the projected domestic energy needs.

To meet domestic demand, Afghanistan imports a tremendous amount of electricity from neighboring countries: Tajikistan (350 MW), Uzbekistan (320 MW), 
Turkmenistan (50 MW), and Iran (108 MW) [11]. Domestic sources come from hydro (263.4 MW), diesel-generator (93.3 MW), and thermal (247.9 MW) power plants [12]. Although it was planned to expand the electricity access rate to $100 \%$ in urban and $65 \%$ in rural by 2032 , it remains a plan [13]. According to the Ministry of Rural Rehabilitation and Development of Afghanistan, at the present only $30 \%$ of Afghan communities have access to electricity, skewed more towards residents in urban rather than rural areas. Accessibility shares, $30 \%$ households use the national grid while $9 \%$ use solar power [14]. The rest (61\%) are non-electrified or powered independently from other sources.

Decentralized renewable energy sources remain the best option to address the problems of increasing electricity demand and establishing a healthier environment especially in rural areas. Distributed Generation (DG), also called dispersed or embedded generation due to its flexibility, controllability, and dispatchability merits, has been widely attracted for reactive power compensation, renewable to grid integration, load control, and overall system stability and reliability improvement tool $[15,16]$. In addition, distributed generation can contribute a system instability and act as a preventive tool for voltage collapse by reactive power compensation, network loadability adjustment, and network re-configuration [17].

\section{Afghanistan from the SDGs perspective}

Balancing of essential dimensions (security of supply, climate and environmental impact, competitiveness) of energy resources in terms of primary sources (extracted or captured directly, i.e. fossil fuels: coal, crude oil, natural gas, nuclear fuel) and secondary sources (produced or converted from the primary energy sources) are known exigence [18]. Renewable energy resources and technologies deployment along with improvement of technical, and economic efficiencies can lead the Afghanistan energy sector towards self-sufficiency. That requires viable strategies and policies aligned with today's technologies [19].

Despite holding a high potential for renewable energy sources, Afghanistan has been addressing its energy needs by importing electricity from neighboring countries. In this paper we analyze the benefits of using these renewable energy sources for self-sustainable development. This analysis identifies available domestic renewable energy sources and the existing barriers restricting their development and deployment using surveys conducted by the World Bank and with personal interviews. The aim of this study evaluates Afghanistan's renewable energy potential for sustainable development and examines challenges for transition.

In 2015, the United Nations (UN) defined 17 goals and 169 targets with the vision of poverty reduction, planet protection, and global peace, for sustainable development of the world. These goals and targets are intended to improve the quality of life for the global population and not harm future generations [20]. SDG-7 ensures access to affordable, reliable, sustainable, and modern energy for all that focuses on three main areas: renewable energy, efficiency, and access that is identifying five targets [21]:

1- Universal access to clean and affordable energy services.

2- Increase the contribution of renewable energy to the global energy mix.

3- Double the global rate of improvement in energy efficiency.

4- Enhance international cooperation and investment in renewable energy technologies and growth.

5- Expand infrastructure and upgrade technology for supplying modern and sustainable energy services to all communities in emerging nations.

Because energy demand increases as population rises, energy production from non-renewable sources contributes to climate change and environmental damage. Investment in renewable energy sources - such as hydro, solar, biomass, wind, and thermal - can fulfill the demand through universal access to cheap and affordable electricity. To meet this goal by 2030, global residential and industrial electricity consumption needs to be reduced by $14 \%$ and cost-effective adoption of technology can help manage the demand. By encouraging developing countries to enhance their infrastructure and upgrade technologies to offer clean energy, they offer opportunities for environmental, socioeconomic, and political improvements. Moreover, investment in renewable energy is expected to create employment opportunities from 10.3 million in 2017 to 24 million in 2030 [22].

Afghanistan's strategy to address sustainable development goals occurs in three phases: nationalization, alignment, and implementation. Responsible for developing plans that meet the vision of the SDGs, the government coordinates the establishment of institutional processes for national planning, including security, education, health, social protection, infrastructure, agriculture, governance, and economy. The nationalization phase sets targets and defines metrics to monitor progress [23]. After goals are approved, alignment establishes tools, guidelines, and milestones to achieve the desired national targets. Approval of nationalized indicators and targets the phase of alignment is starting to state national strategies, policies and plans achieving the national targets and indicators [23]. The implementation process started in 2018 with progress reports occurring every three years until 2030.

Socioeconomic changes further underscore the urgency of these changes. Poverty increased in Kabul from 36\% (2011-2012) to 39\% (2013-2014) [24]. Improvements in maternal health metrics are beginning to slow down. Poor children are more likely to drop out of school [25]. If the Afghan government wants to make SDG-7 a priority, 
commitment and investment to provide reliable, sustainable clean energy must be made in creating an efficient energy generation, delivery, and distribution infrastructure.

\section{Renewable source assets in Afghanistan}

Hydro, solar, and wind power are excellent renewable energy options for Afghanistan. Geothermal energy also holds potential value but has not been analyzed as completely. Biomass sources from agricultural waste are widely used for cooking and heating but can also serve as a source to generate renewable energy. In the following sections, each renewable energy source is discussed in detail.

\subsection{Hydropower}

Hydroelectric power is the most widely used source of renewable energy, contributing over $1000 \mathrm{GW}(16 \%)$ of the world's net overall energy production [26]. China is the world's largest generator of hydroelectric power. In 1893, the first power generation was operated in Kabul; and the first commercialized hydropower plant (Jabal Seraj) constructed in 1916 on the Salange Revier at an altitude of $1600 \mathrm{~m}$ above the sea level; and has been operating since 1922 [27].

Hydropower from mountain sources is estimated to generate more than $23 \mathrm{GW}$ of power [4]. Most of this energy (approximately $20 \mathrm{GW}$ ) can come from the northeastern ranges (Amu Darya, Panj, and Kokcha). Mountains from the east of Kabul can provide $19 \mathrm{GW}$ while Balkh and Jowzan regions in the north-west can provide $800 \mathrm{MW}$. Remaining hydropower supply (about $500 \mathrm{MW}$ ) can come from west-central part of Afghanistan.

Up until now, the full capability of hydroelectric energy has not been utilized. Total usage in March 2016 was 256 MW. The completion of the Salma dam renovation in mid2016 provided $42 \mathrm{MW}$ of additional power (total power $330 \mathrm{MW}$ ).

Table 1: Table 1: Some of hydro power plants in Afghanistan [28].

\begin{tabular}{llll}
\hline \hline No. & Power Station & $\begin{array}{l}\text { Capacity after Rehabilita- } \\
\text { tion (MW) }\end{array}$ & System \\
\hline 1 & Naghlu & 100 & Kabul \\
2 & Salma & 42 & Herat \\
3 & Sarobi & 22 & Kabul \\
4 & Mahipar & 66 & Kabul \\
5 & Durunta & 11.5 & Kabul \\
6 & Assassab & 0.7 & Kunar \\
7 & Charikar & 2.4 & Gorband \\
8 & Jabul Seraj & 2.5 & Salang \\
9 & Ghorban & 0.3 & Gorband \\
10 & Kajaki & 33 & Helmand \\
11 & Grishk & 2.4 & Helmand \\
12 & Pul-e-Chomri & 5.12 & Pulikhumri \\
13 & Pul-e-Chomri 2 & 8.79 & Pulikhumri \\
\hline
\end{tabular}

Table 2: Afghanistan hydropower estimated capacity based on river region [29].

\begin{tabular}{lll}
\hline \hline No & Hydro System/Region & Capacity (MW) \\
\hline 1 & Kabul & 1,941 \\
2 & Panj-e-Amu & 20,137 \\
3 & Shamali & 760 \\
4 & Harirod & 202 \\
5 & Pul-e-Chomri 2 & 8.79 \\
& Total & 23,310 \\
\hline \hline
\end{tabular}

Additional smaller hydropower plants are mostly located in rural areas which specifically generate electricity for community lighting purposes. The total hydro power available by system/region is listed:

Deliberate investment in hydropower will help realize the benefits of sustainable energy. With abundant hydropower, poverty could be mitigated or eliminated by creating employment opportunities, attracting tourists, increasing economic activity, and building effective governmental infrastructure. By constructing dams, the ground water supply could be replenished and greenhouse gas emissions reduced. Increasing hydropower capacity also supports increased biodiversity and better quality of life.

\subsection{Wind energy}

Wind energy provides 539.123 GW globally and is the second largest renewable energy resource with an annual growth of $12.6 \%$ [30]. China is the leading global producer of wind energy. Afghanistan has great potential as a producer of wind energy. It is estimated that with wind speeds exceeding $6.8 \mathrm{~m} / \mathrm{s}, 150 \mathrm{GW}$ can be produced, and the total amount of usable energy is $67 \mathrm{GW}$ [31].

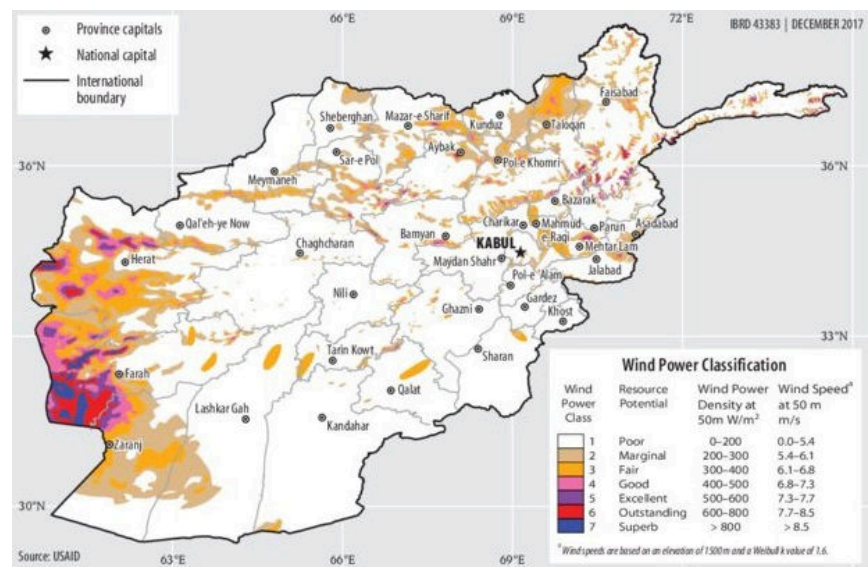

Figure 1. Afghanistan wind resources potential [32].

The table below provides the overall wind area, wind energy potential and capacity of wind energy in Afghanistan.

Table 3: Afghanistan wind resource per province [33]. 


\begin{tabular}{|c|c|c|c|c|}
\hline No. & Province & $\begin{array}{l}\text { Wind Area } \\
(\mathrm{km} 2)\end{array}$ & $\begin{array}{l}\text { Estimated Potential } \\
(\mathrm{MW}) \text { (wind class } 6.8 \\
>8.5 \text { ) }\end{array}$ & $\begin{array}{l}\text { Feasile } \\
\text { Capacity }\end{array}$ \\
\hline 1 & Badakhshan & 1,428 & 3,314 & 331 \\
\hline 2 & Badghis & 410 & 762 & 191 \\
\hline 3 & Baghlan & 1,064 & 2,083 & 208 \\
\hline 4 & Balkh & 1,698 & 3,145 & 766 \\
\hline 5 & Bamyan & 100 & 240 & 24 \\
\hline 6 & Daikondi & - & - & - \\
\hline 7 & Farah & 19,270 & 61,353 & 30,677 \\
\hline 8 & Faryab & 560 & 1008 & 552 \\
\hline 9 & Ghazni & 93 & 191 & 48 \\
\hline 10 & Ghur & 160 & 336 & 84 \\
\hline 11 & Helmand & 1,040 & 1,872 & 936 \\
\hline 12 & Herat & 14,694 & 36,947 & 18,473 \\
\hline 13 & Jozjan & 95 & 171 & 43 \\
\hline 14 & Kabul & 230 & 414 & 41 \\
\hline 15 & Kandahar & 130 & 234 & 117 \\
\hline 16 & Kapisa & 450 & 810 & 81 \\
\hline 17 & Khost & - & - & - \\
\hline 18 & Kondoz & 180 & 324 & 81 \\
\hline 19 & Kunr & 40 & 72 & 7 \\
\hline 20 & Laghman & 460 & 1,020 & 255 \\
\hline 21 & Logar & - & - & - \\
\hline 22 & Nangrhar & 300 & 582 & 146 \\
\hline 23 & Nemroz & 10,130 & 21,450 & 10,725 \\
\hline 24 & Noristan & 90 & - & - \\
\hline 25 & Paktia & - & - & - \\
\hline 26 & Paktika & 220 & 396 & 99 \\
\hline 27 & Panjshir & 80 & 180 & 18 \\
\hline 28 & Parwan & 705 & 1,269 & 127 \\
\hline 29 & Samangan & 503 & 1,064 & 266 \\
\hline 30 & Sar-e-pol & 385 & 729 & 182 \\
\hline 31 & Takhar & 2,547 & 4,795 & 1,199 \\
\hline 32 & Uruzgan & 650 & 990 & 495 \\
\hline 33 & Wardak & 80 & 180 & 18 \\
\hline \multirow[t]{2}{*}{34} & Zabul & 860 & 1,632 & 816 \\
\hline & Total & 58,543 & 147,563 & 66,726 \\
\hline
\end{tabular}

Approximately $90 \%$ of the wind capacity is located in three western provinces Herat, Farah and Nimroz. However, there is no national electrical delivery network that connects these provinces to other parts of the country. It is imperative that these provinces will be connected to the national grid.

\subsection{Solar energy}

Producing and delivery of solar energy require different technologies to interface with conventional existing energy grids. By 2017, global solar energy production was 405 GW while concentrated solar-thermal energy production was $5.1 \mathrm{GW}$, with China, Germany, Italy, and the U.S. as the largest producers [34].

Afghanistan can also potentially produce $220,000 \mathrm{MW}$ of solar power with 300 sunny days each year and can generate $6.5 \mathrm{kWh} / \mathrm{m}^{2}$ [31]. The southern and western parts of Afghanistan receives even more direct sunlight and can potentially generate $1022 \mathrm{KW} / \mathrm{m} 2$ /year or more with the installation of concentrating solar power (CSP) [35].

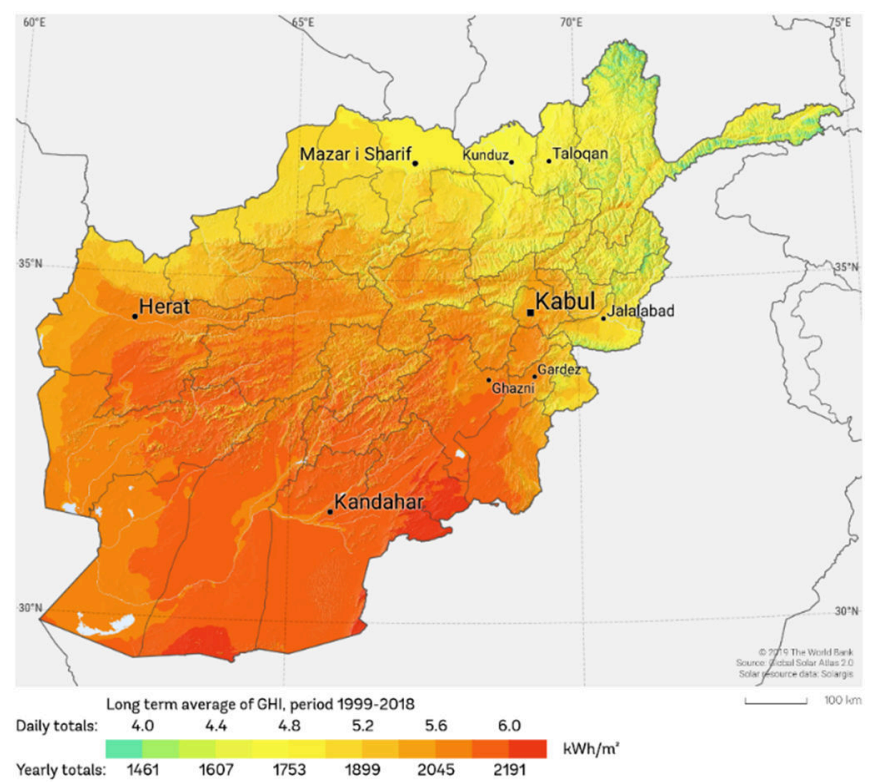

Figure 2. Afghanistan global horizontal irradiation [36].

The Afghanistan government along with other entities have been promoting development of solar energy integration with the existing electrical grid to help with rural electrification. Table 4 shows the solar potential energy capacity by province.

Table 4: Afghanistan solar resource per province [33].

\begin{tabular}{lll}
\hline No. & Province & Estimated Capacity (MW) \\
\hline 1 & Kabul & 432 \\
2 & Kapisa & 183 \\
3 & Parwan & 548 \\
4 & Wardak & 1,043 \\
5 & Logar & 451 \\
6 & Ghazni & 5,802 \\
7 & Paktia & 5,042 \\
8 & Khost & 364 \\
9 & Nangarhar & 1,687 \\
10 & Kunar & 447 \\
11 & Laghman & 842 \\
12 & Nooristan & 888 \\
13 & Badakhshan & 3,736 \\
14 & Bamyan & 1,863 \\
15 & Takhar & 2,543 \\
16 & Baghlan & 1,536 \\
17 & Kundoz & 1,279 \\
18 & Samanagan & 2,912 \\
19 & Balkh & 2,900 \\
20 & Jozjan & 2,230 \\
21 & Sar-e-pol & 4,131 \\
22 & Faryab & 4,679
\end{tabular}




\begin{tabular}{lll}
23 & Badghis & 5,328 \\
24 & Herat & 28,539 \\
25 & Farah & 27,137 \\
26 & Ghur & 10,539 \\
27 & Helmand & 33,282 \\
28 & Nemroz & 22,618 \\
29 & Kandahar & 31,079 \\
30 & Zabul & 9,464 \\
21 & Uruzgan & 6,530 \\
32 & Daikondi & 1,911 \\
33 & Panjshir & 510 \\
34 & Paktika & 374 \\
& Total & 222,849 \\
\hline
\end{tabular}

\subsection{Geothermal}

Geothermal energy production relies on steam and hot water from active geothermal areas of the earth and can be used to heat houses or generate electricity. Additional research is needed to assess Afghanistan's geothermal energy potential. Geologically, Afghanistan lies on three tectonic plates whose motion and collision result in hot springs, hydrothermal minerals, volcanoes, and magma rocks. Consequently, the greatest opportunity to tap into geothermal energy may lie in the southern, eastern, and western parts of the country [37].

\subsection{Biomass}

A majority of Afghans work in agriculture and ranching, so biomass sources are plentiful and meet roughly $85 \%$ of their energy demand. Afghanistan's potential to produce clean energy from biomass is around 4GW. The Ministry of Energy and Water itemizes each province's potential for biomass clean energy production.

Table 5: Afghanistan biomass resources per province [33].

\begin{tabular}{lllll}
\hline \hline \multirow{2}{*}{ No. } & Province & \multicolumn{3}{l}{ Biomass Capacity (MWh/year) } \\
\cline { 3 - 5 } & & $\begin{array}{l}\text { Municipal } \\
\text { Solid Waste }\end{array}$ & Animal Dang & $\begin{array}{l}\text { Agriculture } \\
\text { Waste }\end{array}$ \\
\hline 1 & Kabul & 126,884 & 69,089 & 465,372 \\
2 & Kapisa & 13,848 & 171,438 & 442,103 \\
3 & Parwan & 20,287 & 16,028 & 565,369 \\
4 & Wardak & 18,231 & 84,917 & 529,715 \\
5 & Logar & 11,984 & 72,713 & 842,423 \\
6 & Ghazni & 37,542 & 227,860 & $1,343,574$ \\
7 & Paktia & 13,291 & 144,569 & 475,755 \\
8 & Khost & 17,563 & 367,769 & 376,509 \\
9 & Nangarhar & 46,124 & 626,687 & $1,749,774$ \\
10 & Kunar & 13,773 & 313,913 & 449,026 \\
11 & Laghman & 13,622 & 269,201 & 654,148 \\
12 & Nooristan & 4,526 & 156,503 & 93,491 \\
13 & Badakhshan & 29,029 & 452,658 & 598,604 \\
14 & Bamyan & 13,667 & 143,149 & 286,562 \\
15 & Takhar & 29,990 & 269,732 & $1,524,344$ \\
16 & Baghlan & 27,742 & 296,943 & $1,442,236$ \\
17 & Kundoz & 30,636 & 388,437 & $1,863,114$ \\
18 & Samanagan & 11,846 & 53,134 & 416,541 \\
19 & Balkh & 39,993 & 196,478 & $1,731,926$ \\
& & & &
\end{tabular}

\begin{tabular}{lllll}
20 & Jozjan & 16,449 & 75,809 & 906,725 \\
21 & Sar-e-pol & 17,086 & 124,985 & 616,743 \\
22 & Faryab & 30,450 & 182,730 & $1,350,830$ \\
23 & Badghis & 15,157 & 148,016 & 577,837 \\
24 & Herat & 28,250 & 382,275 & $2,013,776$ \\
25 & Farah & 15,495 & 162,717 & 375,425 \\
26 & Ghur & 21,109 & 232,387 & 406,450 \\
27 & Helmand & 57,174 & 424,513 & $1,732,510$ \\
28 & Nemroz & 5,030 & 47,449 & 299,114 \\
29 & Kandahar & 36,973 & 406,866 & $1,111,055$ \\
30 & Zabul & 9,292 & 70,405 & 261,469 \\
21 & Uruzgan & 10,712 & 159,410 & 584,592 \\
32 & Daikondi & 14,085 & 209,599 & 194,405 \\
33 & Panjshir & 16,863 & 237,601 & 616,076 \\
34 & Paktika & 4,693 & 37,076 & 185,815 \\
& Total & 819,396 & $7,367,282$ & $27,083,408$ \\
\hline
\end{tabular}

With energy capacities from hydro (23 GW), wind (67 $\mathrm{GW})$, solar (220 GW), and biomass (4 GW), Afghanistan can export energy to other southeast Asian nations and fulfill its own energy needs. Here are some of the challenges in developing renewable energy in Afghanistan.

\section{Barriers for renewable energy development}

\subsection{Security and political barriers}

Political instability undermines any data collecting efforts needed for proper planning. It is difficult to access reliable information about the Afghanistan energy sector due to lack of cooperation culture and modern data storing and sharing facilities. Alternatively, most of the available information is sketchy, anecdotal, piecemeal, and often conflicting [10]. Also, post-conflicts, provincial warlords, insurgent groups, and the weak central government challenges any diplomatic relationships that could help address the nation's energy demands.

\subsection{Technical barriers and shortage of field profes- sionals}

While a national electric grid exists, it does not cover all parts of the country. Most southern and central areas of the country do not have access to the grid. Other sections of the grid have limited capacities, making meeting voltage and frequency mismatches challenging to integrate new renewable resources. However, there is no update and inclusive information about energy sector technical and financial losses, the power networks losses reported near to $40 \%$ with an average annual loss of 2 million (USD) [38]. The lack of a central data monitoring system to measure national demand prevents any investment in sustainable energy projects. Afghanistan also lacks technical experts and energy workers experienced in clean energy. The country still suffers from high unemployment while foreign-born workers are involved in large energy projects across the country.

\subsection{Economic barrier}


Though there are improvements in life expectancy, literacy, and per capita income since 2001, the country suffers from poverty and is dependent on foreign aid. Most citizens lack access to electricity, clean water, health care, and jobs. Political instability, corruption, and subjective legal enforcement hinders future economic growth and does not promote a commitment to invest in the high initial costs for addressing these issues. Investments are made in dollars as tax revenue is collected in the more unstable Afghani. The Afghanistan Land Authority oversees land development only has $30 \%$ of urban and $10 \%$ of rural property registered [39]. Furthermore, the domestic banking and investment infrastructure remains focused in the big cities. Investment in renewable energy projects carries the financial risk that few investors are eager to accept. Microfinancing processes also prevent investment in small projects.

\subsection{Legal and regulatory framework}

Policies and regulations for rural electrification, renewable energy, and developing agreements for international power purchasing have been developed, but the World Bank reports there lacks a realistic process or timeline for implementation. The Renewable Energy Policy encourages DABS but does not mandate a purchasing scheme. Private-sector development is encouraged to support building and expansion of mini-grids and off-grid projects, but a central strategic plan is still needed.

\subsection{Poor community awareness}

Educating the public on the benefits of renewable energy - such as its potential socioeconomic impact - is ineffective in developing counties, including Afghanistan.

\section{Conclusions and recommendations}

Afghanistan can benefit from its high renewable energy resources of hydro, solar, wind, geothermal, and biomass to make progress towards the Sustainable Development Goals and SDG-7. To maximize these assets, Afghanistan must overcome significant barriers as identified in this research. The following are suggestions.

- Build training and employment opportunities: Investing in education and training should build a domestic community of technical professionals who can build and manage the integration of renewable energy sources, develop new technologies, and upgrade the existing power supply network. The current number of vocational training facilities needs to be increased and improved.

- Provide risk insurance for renewable energy projects: The government should provide risk insurance to pr- omote renewable energy projects throughout the country. This should motivate banks, investors, and microcreditors to engage the public's interest in construction of these infrastructural improvements towards sustainable energy goals.

- Improve existing policies and enforce regulations: Making a fitting decision for deployment cost-effective renewable energy technologies, which requires viable polices and a profound technical, managerial, and interdisciplinary knowledge and expertise to lead Afghanistan toward self-sufficiency. This objective can be achieved by conducting exhaustive research to provide a market-based energy development framework and involves innovative measures, tools, and techniques in terms of a strategic planning and policy development [40].

- Offer incentives favoring renewable energy: However, renewable energy technologies' deployment cost is steadily decreased (i.e., the average price of solar panels dropped about $60 \%$ since 2011 [18]), still high initial investment is a challenge. Because the overall cost of energy from renewable sources is higher than current non-renewable sources, market incentives should be offered to encourage switching to renewable energy. Therefore, well-management of payback, cash flow, tax-in-tariffs and other financial initiatives to encourage public and private sectors for an active engagement are necessary.

- Increase public awareness: Educating the importance of sustainable energy should encourage the public increase its awareness and use within the energy grid. Lack of stakeholders and beneficiaries of energy projects' awareness from potential benefits of the investment lifecycle in the long-term is reported [41]. This problem along with many others linked with improper decision-making and inadequate policy development. In which, missing decision-making standard process and procedure (on time, and budget and risks), external and internal factors' evaluation (economic, political, behavioral, and cultural), interest to control wholesale markets, etc. leads to instant responses instead of sustainable solutions [42]. Using Information and Communications Technology (ICT) for public awareness, information broadcasting, and more importantly for local engagement is recommended [43].

- At last, renewable energy resources in Afghanistan estimates $330 \mathrm{GW}$, sufficient to meet it domestic energy demand. However, deployment and integration of these resources are challenging and requires political commitment, academic and technical studies, and a strong economy. 


\section{References}

[1] Energy and climate change (2015) WEO-2015 Special Report Paris, France, International Energy Agency (IEA). (https://webstore.iea.org/weo-2015-special-report-energy-and-climate-change) Accessed: 7 April 2020

[2] Global energy demand grew by $2.1 \%$ in 2017 , and carbon emissions rose for the first time since 2014 (2018) International Energy Agency (AEI) (https://www.iea.org/news/ global-energy-demand-grew-by-21-in-2017-and-carbonemissions-rose-for-the-first-time-since-2014) Accessed: 7 April 2020

[3] Ekouevi K, Tuntivate V (2012) "Household energy access for cooking and heating: lessons learned and the way forward," 1st ed. Washington DC, USA, The World Bank. p. ISBN: 978-1-78076-013-1

[4] Masih Sediqi M, Or Rashid Howlader H, Matin Ibrahimi A, Sayed Shah Danish M, Rahman Sabory N, et al. (2017) "Development of renewable energy resources in Afghanistan for economically optimized cross-border electricity trading" AIMS Energy (vol. 5, no. 4, pp. 691-717) https://doi.org/10.3934/energy.2017.4.691

[5] Afghanistan population (2020) - Worldometer (2020) Worldometer (https://www.worldometers.info/worldpopulation/afghanistan-population/) Accessed: 7 April 2020

[6] Rezaei M, Naghdi-Khozani N, Jafari N (2020) "Wind energy utilization for hydrogen production in an underdeveloped country: An economic investigation" Renewable Energy (vol. 147, pp. 1044-1057) https://doi.org/10.1016/ j.renene.2019.09.079

[7] Danish MSS, Senjyu T, Sabory NR, Danish SMS, Ludin GA, et al. (2017) "Afghanistan's aspirations for energy independence: Water resources and hydropower energy" Renewable Energy (vol. 113, pp. 1276-1287) https://doi.org/ 10.1016/j.renene.2017.06.090

[8] Jahangiri M, Haghani A, Mostafaeipour A, Khosravi A, Raeisi HA (2019) "Assessment of solar-wind power plants in Afghanistan: A review" Renewable and Sustainable Energy Reviews (vol. 99, pp. 169-190) https://doi.org/10.1016/ j.rser.2018.10.003

[9] Ershad AM (2017) "Institutional and policy assessment of renewable energy sector in Afghanistan" Journal of Renewable Energy (vol. 2017, pp. e5723152) https://doi.org/ $10.1155 / 2017 / 5723152$

[10] Danish MSS, Sabory NR, Danish SMS, Senjyu T, Ludin GA, et al. (2017) "Electricity sector transitions in an after war country: A review of Afghanistan's Electricity" Journal of Energy and Power Engineering (vol. 11, no. 1, pp. 491-496) https://doi.org/10.17265/1934-8975/2017.07.008

[11] Electricity imports statistics (2017) Kabul, Afghanistan, $D a$ Afghanistan Breshna Sherkat (DABS).

[12] Domestic hydro generation (2020) Afghanistan Inter-Ministerial Commission for Energy (ICE) (https://sites.google.com/site/iceafghanistan/electricitysupply/domestic-generation-1/domestic-hydro-generation) Accessed: 7 April 2020

[13] Danish MSS, Sabory NR, Danish SMS, Senjyu T, Ludin GA, et al. (2017) "Electricity sector development trends in an after-war country: Afghanistan aspiration for an independent energy country" Journal of Energy and Power Engineering (vol. 11, no. 1, pp. 553-557) https://doi.org/10.17265/ 1934-8975/2017.08.007

[14] Bank AD (2015) "Sustainable energy for all status report: tracking progress in the Asia and the Pacific: A summary report," 1st ed. Asian Development Bank. 158 p. ISBN: 97892-9257-112-2

[15] Yaqobi MA, Matayoshi H, Danish MSS, Lotfy ME, Howlader AM, et al. (2019) "Low-voltage solid-state DC breaker for fault protection applications in isolated DC microgrid cluster" Applied Sciences (vol. 9, no. 4, pp. 723-735) https://doi.org/10.3390/app9040723

[16] Danish MSS, Matayoshi H, Howlader HOR, Chakraborty S, Mandal P, et al. (2019) "Microgrid planning and design: Resilience to sustainability" Bangkok, Thailand, IEEE

[17] Danish MSS, Senjyu T, Danish SMS, Sabory NR, K N, et al. (2019) "A recap of voltage stability indices in the past three decades" Energies (vol. 12, no. 8, pp. 1544) https://doi.org/10.3390/en12081544

[18] Danish MSS, Sabory NR, Ershad AM, Danish SMS, Yona A, et al. (2017) "Sustainable architecture and urban planning trough exploitation of renewable energy" International Journal of Sustainable and Green Energy (vol. 6, no. 3, pp. 17) https://doi.org/10.11648/j.ijrse.s.2017060301.11

[19] Danish MSS, Sabory NR, Danish SMS, Ludin GA, Yona A, et al. (2016) "An open-door immature policy for rural electrification: A case study of Afghanistan" International Journal of Sustainable and Green Energy (vol. 6, no. 3, pp. 8-13) https://doi.org/10.11648/j.ijrse.s.2017060301.12

[20] Georgeson L, Maslin M (2018) "Putting the United Nations sustainable development goals into practice: A review of implementation, monitoring, and finance" Geo: Geography and Environment (vol. 5, no. 1, ) https://doi.org/10.1002/geo2.49

[21] Goal 7-Affordable and clean energy (2020) Energy - United Nations Sustainable Development (https://www.un.org/ sustainabledevelopment/energy/) Accessed: 7 April 2020

[22] Renewable energy and jobs: Annual teview 2018 (2018) Abu Dhabi, UAE, International Renewable Energy Agency (IRENA). (https://irena.org/-/media/Files/IRENA/ Agency/Publication/2018/May/IRENA_RE_Jobs_Annual_Review_2018.pdf) Accessed: 4 July 2020

[23] Voluntary national review at the high level political forum SDGs' - Afghanistan (2017) Progress report Kabul, Afghanistan, General Directorate of Policy \& RBM, Ministry of Economy. (https://sustainabledevelopment.un.org/content/documents/16277Afghanistan.pdf) Accessed: 4 July 2020

[24] Afghanistan poverty status update - Progress at risk (2017) World Bank (https://www.worldbank.org/en/ country/afghanistan/publication/afghanistan-povertystatus-update-report-2017) Accessed: 7 April 2020

[25] Najafizada SAM (2017) "Policy research institutions and the health SDGs: building momentum in South Asia" Country Report: Afghanistan Kabul, Afghanistan, Afghanistan Research and Evaluation Unit (AREU). (https://idl-bncidrc.dspacedirect.org/handle/10625/57091) Accessed: 7 April 2020

[26] Renewables 2016: Global status report (2017) Paris, France, REN21 Secretariat. (https://www.ren21.net/wp- 
content/uploads/2019/05/REN21_GSR2016_FullReport_en_11.pdf) Accessed: 4 July 2020

[27] Danish MSS, Funabashi T (2014) "Explicit recognition of Afghanistan's power distribution networks problems and technical suggestions" 2014 IEEE Region 10 Conference (TENCON) Bangkok, Thailand, IEEE - pp. 1-6. https://doi.org/10.1109/TENCON.2014.7022402 (https://ieeexplore.ieee.org/document/7022402)

[28] Ministry of Energy and Water (MEW) - Afghanistan (2017) "Afghanistan hydropower plants" (www.mew.gov.af) Accessed: 4 July 2019

[29] Afghanistan renewable energy policy (2017) (Afghanistan Renewable Energy Policy) Accessed: 16 November 2019

[30] Statistics (2019) Global wind energy council (https://gwec.net/members-area-market-intelligence/statistics/) Accessed: 7 April 2020

[31] Country presentation - The South Asian Association for Regional Cooperation (SAARC) (2016)

[32] Gencer, Irving, Meier, Spencer, Wnuk C (2018) “Energy security trade-offs under high uncertainty: Resolving Afghanistan's power sector development dilemma" Kabul, Afghanistan, World Bank. (https://www.researchgate.net/publication/326331194_Energy_security_trade-offs_under_high_uncertainty_Resolving_Afghanistan\%27s_power_sector_development_dilemma) Accessed: 7 April 2020

[33] Ministry of Energy and Water (MEW) - Afghanistan (2019) "MEW statistics" (http://mew.gov.af/) Accessed: 4 July 2019

[34] Global solar capacity grew faster than fossil fuels in 2017 (2018) Carbon Brief (https://www.carbonbrief.org/ global-solar-capacity-grew-faster-than-fossil-fuels-2017report) Accessed: 7 April 2020

[35] Renewable energy roadmap for Afghanistan (2015-2017) (2017) Kabul, Afghanistan, Asian Development Bank (ADB). (https://www.adb.org/sites/default/files/project-document/151922/47266-001-tar.pdf) Accessed: 1 November 2019
[36] Global solar atlas - Afghanistan (2019) global solar atlas (https://globalsolaratlas.info/download/afghanistan) Accessed: 7 April 2020

[37] Anwarzai MA (2018) "Research and analysis of Afghanistan's wind, solar, and geothermal resources potential" (Doctoral Dissertation) Tokyo, Japan, Search Results Web results Tokyo University of Agriculture and Technology (https://tuat.repo.nii.ac.jp/?action=repository_action_common_download\&item_id=1487\&item_no $=1 \&$ attribute_id=16\&file_no=1) Accessed: 4 April 2020

[38] Danish MSS, Yona A, Senjyu T (2013) "A brief outlook of Afghanistan electricity" IEEJ Procedding Okinawa, Japan, IEEJ, vol. OKI-2013-51 -

[39] Afghanistan Independent Land Authority (2019) Development aid (https://www.developmentaid.org/) Accessed: 7 April 2020

[40] Danish MSS, Senjyu T, Zaheb H, Sabory NR, Ibrahimi AM, et al. (2019) "A novel transdisciplinary paradigm for municipal solid waste to energy" Journal of Cleaner Production (vol. 233, pp. 880-892) https://doi.org/10.1016/j.jclepro.2019.05.402

[41] Danish MSS, Zaheb H, Sabory NR, Karimy H, Faiq AB, et al. (2019) "The Road Ahead for Municipal Solid Waste Management in the 21st Century: A Novel-standardized Simulated Paradigm" IOP Conference Series: Earth and Environmental Science (vol. 291, pp. 012009) https://doi.org/10.1088/1755-1315/291/1/012009

[42] Danish MSS, Senjyu T (2020) "Green building efficiency and sustainability indicators" Green building management and smart automation: , 1st ed. Pennsylvania, United States, IGI Global - pp. 128-145. https://doi.org/10.4018/ 978-1-5225-9754-4

[43] Danish MSS, Senjyu T, Yaqobi MA, Nazari Z, Matayoshi H, et al. (2018) "The role of ICT in corruption elimination: A holistic approach” 2018 IEEE 9th Annual Information Technology, Electronics and Mobile Communication Conference (IEMCON) Vancouver, BC, Canada, IEEE - pp. 859-864. https://doi.org/10.1109/IEMCON.2018.8614890 